Año 9. Núm. 24

(Edición especial julio- diciembre 2016)
Revista de Investigación

Académica sin Frontera

ISSN: 2007-8870

\title{
http://revistainvestigacionacademicasinfrontera.com
}

\section{La violencia económica como una forma de violencia intrafamiliar en el Estado de Sonora.}

Adolfo Alamada Valenzuela

Concepción Corral Hernández

Petra Alicia Navarrete Rivera

\section{Resumen}

Un estudio realizado a fin de que la violencia económica sea tomada en cuenta para incluirse en el tipo de violencia intrafamiliar en el Código Penal para el Estado de Sonora, debido a que la figura jurídica que se maneja actualmente en la legislación sustantiva penal no contempla la violencia económica como tal, sino que se maneja una violencia patrimonial que es diferente en cuanto a su acreditación, conceptualización y tratamiento que se da en otras legislaciones. El incluir la violencia económica como una modalidad de violencia intrafamiliar vendría a dar a quienes sean víctimas de este supuesto, una mayor protección en cuanto a la principal base de nuestra sociedad que lo es la familia y en quien el Estado debe de poner especial atención a fin, de que el tejido social de nuestra Entidad y Estado, no se siga diluyendo. La violencia económica es una realidad que tiene que ser materia de estudio para posteriormente incluirse en la legislación local penal.

Palabras clave: violencia, familia, violencia intrafamiliar, violencia económica, seguridad jurídica. 


\section{INTRODUCCIÓN}

Un estudio realizado a fin de que la violencia económica sea tomada en cuenta para incluirse en el tipo de violencia intrafamiliar en el Código Penal para el Estado de Sonora, debido a que la figura jurídica que se maneja actualmente en la legislación sustantiva penal no contempla la violencia económica como tal, sino que se maneja una violencia patrimonial que es diferente en cuanto a su acreditación, conceptualización y tratamiento que se da en otras legislaciones.

En el contenido de la presente se encuentra una reseña sobre los antecedentes de la violencia intrafamiliar donde se hace mención de que esta figura jurídica es relativamente reciente y que en su proceso ha sufrido varias reformas en su contenido; también se hace alusión a los conceptos jurídicos relacionados con la temática, así como las referencias teóricas a efectos de comprender la información proporcionada.

Además, se analiza el delito de violencia intrafamiliar en otra legislación, para así relacionar y comparar la redacción de esta con el Código Penal para el Estado de Sonora; por último llega a las conclusiones del tema así como una propuesta relacionada a la problemática planteada.

\section{PLANTEAMIENTO DEL PROBLEMA}

La legislación sustantiva penal en Sonora no contempla la violencia económica como un tipo de violencia intrafamiliar, si no que maneja una violencia patrimonial que es diferente en cuanto a su acreditación, conceptualización y tratamiento, como se da en otras legislaciones. 
Año 9. Núm. 24 (Edición especial julio- diciembre 2016)

http://revistainvestigacionacademicasinfrontera.com
Revista de Investigación

Académica sin Frontera ISSN: $2007-8870$

\section{REFERENCIAS TEÓRICAS}

Violencia

En términos comunes se entiende por violencia: la acción o efecto de violentar o violentarse. Acción violenta o contra el natural modo de proceder. Fuerza extrema, o abuso de la fuerza. Fuerza ejercida sobre una persona para obligarla a hacer lo que no quiere. El que obra con ímpetu y fuerza; se deja llevar fácilmente por la ira.

La violencia se da cuando se emplea fuerza física o amenaza (moral), que importen el peligro de perder la vida, la honra, la libertad, la salud o una parte considerable de los bienes (Manuel. F. Chávez Asencio, 2003)

Seguridad jurídica

La seguridad jurídica engloba al menos tres significados: como principio inspirador de todo el ordenamiento jurídico; como sinónimo de certeza y conocimiento de las normas, y como previsibilidad de las consecuencias de determinada actuación, y como ausencia de riesgo en el ejercicio de las libertades que todo ciudadano tiene reconocidas por el derecho, es decir, se entiende como protección personal y seguridad ciudadana.

Familia

La familia es la más antigua de las instituciones humanas y constituye un elemento clave para la comprensión y funcionamiento de la sociedad (Manuel. F. Chávez Asencio, 2003) 


\section{http://revistainvestigacionacademicasinfrontera.com}

Revista de Investigación

Académica sin Frontera ISSN: $2007-8870$

Por violencia intrafamiliar se considera el uso de la fuerza física o moral, así como las omisiones graves que de manera reiterada ejerza un miembro de la familia en contra de otro integrante de la misma que atente contra su integridad física, psíquica o ambas independientemente de que pueda producir o no lesiones; siempre y cuando el agresor y el agredido habiten en el mismo domicilio y exista una relación de parentesco, matrimonio o concubinato.

(2016)

"toda acción u omisión protagonizada por uno o varios miembros de la familia, a otros parientes infringiendo daño físico, psicoemocional, sexual, económico o social"

Violencia Familiar

Es el acto de poder u omisión, único o repetitivo, cometido por un miembro de la familia en contra de otro u otros integrantes de la misma, sin importar si la relación se da por parentesco consanguíneo, de afinidad, o civil mediante matrimonio, concubinato $u$ otras relaciones de hecho, independientemente del espacio físico donde ocurra.

Modalidades de violencia familiar:

Violencia física: Ocurre en forma recurrente y aumenta en frecuencia e intensidad conforme transcurre el tiempo, pudiendo llegar a provocar la muerte, incluye manifestaciones como empujones, puñetazos, bofetadas, sujeción, heridas con armas, quemaduras, mordidas, rasguños, intento de estrangulamiento, etc. Existe una tendencia errónea al considerar como violencia únicamente a las lesiones 
http://revistainvestigacionacademicasinf rontera.com

físicas; así se ha reportado que tres de cada cuatro personas que son víctimas de violencia familiar han sufrido violencia física.

Violencia psicológica o emocional: Es menos reconocida, pero es la más frecuente. Incluye gritos, humillaciones, devaluaciones, amenazas, celos, insultos, amenazas de daño, intimidaciones, críticas constantes, posesividad exagerada, abandono, manipulación, asignación de culpas por todo lo que sucede, aislamiento de familiares y amigos, etc.

Violencia sexual: Todo acto sexual, la tentativa de consumar un acto sexual, los comentarios 0 insinuaciones sexuales no deseados 0 las acciones para comercializar o utilizar de cualquier otro modo la sexualidad de una persona mediante coacción por otra persona. Incluye acciones como insinuaciones sexuales, palabras obscenas, miradas lascivas, tocamientos o intento, manoseo, la exposición de órganos sexuales (exhibicionismo) y de imágenes o relaciones sexuales, pornografía infantil (procurar, obligar, inducir a realizar actos sexuales o de exhibicionismo corporal con el fin de filmar, fotografiar), la violación sexual (introducción del pene en el cuerpo de la víctima por vía vaginal, anal u oral, incluye la introducción de cualquier otra parte del cuerpo u objeto por vía vaginal o anal, por medio de la violencia física o moral), etc. La violencia sexual es la más difícil de referir y desafortunadamente un alto porcentaje de esta violencia ejercida hacia mujeres, niñas y niños es llevada a cabo por varones que son familiares, amistades, personas conocidas o que ejercen el rol de cuidadores o tutores, lo cual dificulta más su detección y el poder brindar un manejo adecuado.

Violencia económica: Alude al control del dinero, a no informar el monto de los ingresos familiares y a impedir el acceso a ellos, así como a la negación al ingreso familiar, con lo cual se impone y somete a una persona de cualquier edad y sexo. 


\section{http://revistainvestigacionacademicasinfrontera.com}

Violencia patrimonial: Se refiere al control del patrimonio, herencia o bienes materiales de cualquier integrante de la familia.

Ricardo Ruiz Carbonell se refiere a la violencia como:

"toda acción u omisión de uno o varios miembros de la familia que de lugar a tensiones, vejaciones $u$ otras situaciones similares en los diferentes miembros de la misma". (Carbonell, 2002)

\section{MARCO JURÍDICO}

\section{Código Penal Para El Estado De Sonora}

Artículo 234-A.- Por violencia intrafamiliar se entiende todo acto de poder u omisión intencional dirigido a dominar, someter, controlar o agredir física, verbal, psicoemocional, sexual o patrimonialmente a cualquier miembro de la familia, y que pueda causar maltrato físico, verbal, psicológico, sexual o daño patrimonial, en los términos de la Ley de Prevención y Atención de la Violencia Intrafamiliar.

Ley De Prevención Y Atención De La Violencia Intrafamiliar Para El Estado De Sonora

Artículo $8^{\circ}$. - Para los efectos de esta Ley se entiende por:

I.- Violencia familiar o intrafamiliar. - Todo acto de poder u omisión intencional dirigido a dominar, someter, controlar o agredir física, verbal, psicoemocional, sexual o patrimonialmente a cualquier miembro de la familia y que pueda causar los siguientes tipos de daño: 


\section{http://revistainvestigacionacademicasinfrontera.com}

Revista de Investigación

Académica sin Frontera ISSN: $2007-8870$

a). - Maltrato Físico. - Todo acto de agresión intencional en el que se utilice parte del cuerpo humano, algún objeto, arma o substancia para sujetar, inmovilizar o causar daño a la integridad física del otro, encaminado hacia su control y sometimiento personal;

b). - Maltrato Verbal. - Todo acto de agresión intencional, ejecutado a través del lenguaje, con el propósito de ofender, agredir, menospreciar, denigrar o humillar a cualquier persona;

c). - Maltrato psicológico. - Todo patrón de conducta consistente en actos u omisiones, cuyas formas de expresión pueden ser: prohibiciones, coacciones, condicionamientos, intimidaciones, amenazas, actitudes devaluatorias, de abandono y que provoquen deterioro, disminución o afectación a la dignidad personal de quien las recibe. Aquel acto que se comprueba que ha sido realizado con la intención de causar daño moral a toda persona receptora de violencia intrafamiliar, será considerado maltrato psicológico en los términos previstos por este artículo, aunque se argumente el nivel educativo y la formación personal del receptor y del generador de violencia;

d). - Maltrato Sexual. - Al patrón de conducta consistente en actos u omisiones cuyas formas de expresión pueden ser: inducir a la realización o aceptación de prácticas o conductas sexuales no deseadas o que generen dolor, así como aquellas que impliquen prácticas de celotipia para el control, manipulación o dominio de la pareja;

e). - Daño Patrimonial. - Cualquier acto u omisión tendiente a apropiarse o destruir el patrimonio del receptor de la violencia, ya sea apoderándose o controlando la libre disposición de sus ingresos o de sus bienes muebles e inmuebles, o bien menoscabando o destruyendo los mismos. 
Año 9. Núm. 24 (Edición especial julio- diciembre 2016)

http://revistainvestigacionacademicasinfrontera.com
Revista de Investigación

Académica sin Frontera ISSN: 2007-8870

\section{METODOLOGÍA}

La información recopilada para la investigación es el resultado de un análisis comparativo entre la legislación del Distrito Federal y la del Estado de Sonora partiendo de lo deductivo a lo inductivo para así llegar a la síntesis donde se encuentran los puntos relevantes del tema.

\section{ANTECEDENTES}

La figura jurídica de la violencia intrafamiliar no siempre ha sido regulada por las leyes, aun cuando siempre ha existido la misma en la convivencia diaria de los grupos sociales denominados familia, es a partir de actos cada vez más frecuentes de violencia dados entre los integrantes de la familia que da pie a la necesaria regulación de este tipo penal.

Como es natural imaginar el hecho de que se encuentre tipificado en la legislación no es garantía de que los actos violentos en la familia dejaran de presentarse puesto que es sabido por experiencia que los delitos se sancionan para disminuir su práctica puesto que sería imposible erradicarlos.

Con respecto a lo anterior Manuel F. Chávez Asencio y Julio A. Hernández Barros hacen el siguiente comentario:

La norma por sí misma no tiene fuerza para cambiar una una conducta individual o social. Se requiere un consenso general y la aceptación. La norma fundamentalmente es educativa. Tiende a lograr la aceptación de las personas para evitar las medidas coercitivas (Manuel. F. Chávez Asencio, 2003) 
http://revistainvestigacionacademicasinf rontera.com

La sociedad a lo largo de la historia tiende a evolucionar, así también, al parejo es que deben cambiar las leyes que la regulan, la violencia intrafamiliar es un delito que no puede ser la excepción dado la importancia del bien jurídico que tutela que es la familia y así se ha hecho como se menciona a continuación:

Esta figura típica surgió en diciembre de 1997 en el entonces Código Penal para el Distrito Federal en Materia de Fuero Común y para toda la República en Materia del Fuero Federal, y el 16 de junio de 2002 en el CPDF. En este último caso, a pesar de tratarse de un tipo penal tan joven, es uno de los más reformados y sigue adoleciendo de muchas fallas. (Requena, 2012)

Este tipo penal ha sufrido cambios conforme pasa el tiempo ya que resulta necesario proteger la integridad de la familia mexicana.

Tal es el caso del Código Penal para el Estado de familia que para salvaguardar el bienestar de las familias sonorenses lo ideal sería que contase con una redacción lo más completa en cuanto al delito en mención paras no dejar ningún supuesto excluido.

Francisco González de la Vega nos ilustra con la reflexión siguiente

La familia ha sido considerada en núcleo principal de la sociedad y, por tal razón, es necesario que desde su origen, organización y estructura sea cada vez más eficiente en la aportación de elementos para que el individuo adquiera las bases y los conocimientos de la buena conducta humana. Por ello, la unión de un hombre y una mujer, fundada en el respeto y la mutua complementación crean hombres y mujeres maduros y responsables, lo contrario, la violencia familiar es preocupación en diversos países y en México, por el impacto y las consecuencias que generan los individuos en las familias y en la sociedad, la víctima de violencia familiar de hoy 
Año 9. Núm. 24 (Edición especial julio- diciembre 2016)

http://revistainvestigacionacademicasinfrontera.com
Revista de Investigación

Académica sin Frontera ISSN: $2007-8870$

puede ser el criminal del mañana. Esto lleva a realizar una adecuada legislación que enfrente y frene este fenómeno creciente en la sociedad mexicana, fundada en la igualdad de derechos. (Vega, 2011)

\section{LEGISLACIÓN DEL DISTRITO FEDERAL}

El código Penal del Distrito Federal menciona que la violencia Intrafamiliar consiste en:

- Violencia física

- Violencia psicoemocional

- Violencia sexual

- Violencia económica

- Violencia patrimonial

- Violencia contra los derechos reproductivos.

Esta legislación comprende los dos tipos de violencia a que se hacemos referencia, la patrimonial y la económica dándole acepciones diferentes, no así en el Estado de Sonora como es el tema que nos ocupa.

Código Penal para el Distrito Federal

ARTíCULO 201. Para los efectos del presente capítulo se entiende por:

I. Violencia física: A todo acto intencional en el que se utilice alguna parte del cuerpo, algún objeto, arma o sustancia para sujetar, inmovilizar o causar daño a la integridad física del otro; 


\section{http://revistainvestigacionacademicasinfrontera.com}

II. Violencia psicoemocional: A toda acción u omisión que puede consistir en prohibiciones, coacciones, condicionamientos, intimidaciones, insultos, amenazas, celotipia, desdén, indiferencia, descuido reiterado, chantaje, humillaciones, comparaciones destructivas, abandono o actitudes devaluatorias, entre otras, que provoquen en quien las recibe alteración autocognitiva y autovalorativa que integran su autoestima o alteraciones en alguna esfera o área de la estructura psíquica de la persona;

III. Violencia Patrimonial: A todo acto u omisión que ocasiona daño ya sea de manera directa o indirecta, a los bienes muebles o inmuebles, en menoscabo de su patrimonio; también puede consistir en la perturbación a la posesión, a la propiedad, la sustracción, destrucción, menoscabo, desaparición, ocultamiento o retención de objetos, documentos personales, bienes 0 valores, derechos patrimoniales 0 recursos económicos;

IV. Violencia Sexual: A toda acción u omisión que amenaza, pone en riesgo o lesiona la libertad, seguridad, integridad y desarrollo psicosexual de cualquier persona;

V. Violencia Económica: A toda acción u omisión que afecta la economía del sujeto pasivo, a través de limitaciones encaminadas a controlar el ingreso de sus percepciones económicas y puede consistir en la restricción o limitación de los recursos económicos, y

VI. Violencia contra los derechos reproductivos: A toda acción u omisión que limite o vulnere el derecho de las mujeres a decidir libre y voluntariamente sobre su función reproductiva, en relación con el número y espaciamiento de los hijos, acceso a métodos anticonceptivos de su elección, acceso a una maternidad elegida y segura, así como el acceso a servicios de aborto seguro en el marco previsto en 
Año 9. Núm. 24

(Edición especial julio- diciembre 2016)

http://revistainvestigacionacademicasinfrontera.com
Revista de Investigación

Académica sin Frontera ISSN: $2007-8870$

los ordenamientos relativos para la interrupción legal del embarazo, a servicios de atención prenatal, así como a servicios obstétricos de emergencia.

La violencia patrimonial alude a la afectación que sufre el sujeto pasivo en cuanto a los bienes, caso desigual es el de la violencia económica que consiste en controlar los ingresos con el propósito de someter al receptor de violencia causándole afectaciones en su integridad como persona.

\section{CONCLUSIONES}

1. El incluir la violencia económica como una modalidad de violencia intrafamiliar vendría a dar a quienes sean víctimas de este supuesto una mayor protección en cuanto a la principal base de nuestra sociedad que lo es la familia.

2. El Estado debe poner especial atención en salvaguardar la integridad de la familia a fin de que el tejido social de nuestra Entidad y Estado no se siga diluyendo.

3. La violencia económica es una situación que no debe pasar desapercibida para la ley.

4. La violencia económica es una realidad que tiene que ser materia de estudio para posteriormente incluirse en la legislación local penal. 
Año 9. Núm. 24 (Edición especial julio- diciembre 2016)

http://revistainvestigacionacademicasinfrontera.com
Revista de Investigación

Académica sin Frontera ISSN: 2007-8870

\section{FUENTES CONSULTADAS}

http://www.stjsonora.gob.mx/acceso informacion/marco normativo/CODIGO\%20P ENAL\%20SONORA\%20-\%20Nuevo\%20sistema.pdf

HTTP://APP.VLEX.COM/\#WW/SEARCH/CONTENT TYPE:4+JURISDICTION:M X/CONCEPTO+DE+SEGURIDAD+JUR\%C3\%8DDICA/P3/WW/VID/275274767 http://historico.juridicas.unam.mx/publica/rev/boletin/cont/95/art/art9.htm http://www.medicinalegal.gov.co/documents/10180/33850/9+Violenciaintrafamiliar. pdf/10708fa9-efb1-4904-a9e6-36377ca8a912

http://www.inprf.gob.mx/opencms/export/sites/INPRFM/transparencia/archivos/viol encia familiar 2012.pdf http://catedraunescodh.unam.mx/catedra/CONACYT/08 EducDHyMediacionEscol ar/Contenidos/Biblioteca/Lecturas-Complementarias/Ricardo Ruiz.pdf http://www.aldf.gob.mx/archivo-d261f65641c3fc71b354aaf862b9953a.pdf

(17 de 10 de 2016). Obtenido de http://historico.juridicas.unam.mx/publica/rev/boletin/cont/95/art/art9.htm

(17 de 10 de 2016). Obtenido de http://www.inprf.gob.mx/opencms/export/sites/INPRFM/transparencia/archiv os/violencia_familiar_2012.pdf

Carbonell, R. R. (2002). La violencia y los Derechos Humanos. México: Comisión Nacional de los Derechos Humanos.

Manuel. F. Chávez Asencio, H. B. (2003). La Violencia Intrafamiliar en la Legislación Mexicana. México: Porúa.

Requena, G. A. (2012). Derecho penal. México: Oxford.

Vega, F. G. (2011). Derecho Penal Mexicano. México: Porrúa. 